\title{
The Livestock Sector and its contributions to the Protein and Energy needs of the Nigerian Population
}

\author{
M. M. INYEINYANG \& I. G. UKPONG* \\ (M.M.I.: School of Agriculture, Policy and Development, University of Reading, United \\ Kingdom; I.G.U.: Department of Agricultural Extension and Management, Federal \\ Polytechnic, Ekowe, Bayelsa State, Nigeria.) \\ *Corresponding author's email: inibeheukpong@gmail.com
}

\begin{abstract}
The study was designed to assess the contributions of the livestock sector to the protein and energy needs of the Nigerian population by 2050 using an annual time series data from 1980 to 2010. Projected population figures from 2012 to 2050 were used to estimate the extra amount of protein and energy that will be required by the population in 2050. Energy and protein supply data from animal-derived foods, mainly; cattle meat and milk, sheep meat, goat meat, poultry eggs and meat, from 1980 to 2010 were calculated using animal production data and McCance and Widdowson's composition of foods. The data were analysed using an Excel spreadsheet programme. The result showed that animal-derived foods contributed a total of 47,805,756 $\mathrm{MJ} / \mathrm{d}$ of energy and $1,027,901 \mathrm{~kg} / \mathrm{d}$ of protein in 2010 . Meanwhile, to meet the additional energy and protein needs of the projected Nigerian population of 389.615 million people by 2050 , animal-derived foods would have to supply $37.4 \%$ more energy and $9.0 \%$ more protein than in 2010. The results thus indicate a gap between current production and expected protein and energy requirement of the population by 2050 ; which must be closed if food security is to be achieved.
\end{abstract}

Keywords: Animal production; animal-derived food; energy requirement; livestock sector; Nigerian population; protein needs

Research and development note. Received 07 Jun 2019; revised 06 Sep 2019

\section{Introduction}

Most nations in the world are currently facing an unprecedented increase in population and environmental issues which have posed a threat to food security in the respective countries (Huang \& Ukpong, 2019). To feed this growing population, there has to be a corresponding increase in food production (Crentsil \& Ukpong, 2014).
Food is a basic necessity for human survival because it supplies major nutrients needed for the overall function of the body. Food and Agriculture Organization (FAO) definition of food includes livestock products, oils, and cereals (FAOSTAT, 2010). However, other products such as sugar, vegetables, fruits, pulses, roots and tubers have been included in this definition (Diaz- Bonilla et al., 2000).

Ghana Jnl Agric. Sci. 54 (2), 86 - 97

GJAS is an Open Access Journal and distributed under the terms of the Creative Commons (CC) License [CC BY 4.0] 
Food insecurity is one of the dimensions of poverty, and it entails access to food (quality and quantity), and availability of food (supply and entitlement) (Young et al., 2001). Food poverty can be described as the inability to afford enough food that can be considered adequate to provide the required amount of protein and energy needed by the human body within a particular time, and livestock production is a contributing factor to this quality food needs. The contribution of livestock varies from household to household depending on the income level. Some livestock keepers sell their stocks for money to purchase food grains, cereals and vegetables, while others keep the smaller mammals for food, hence the consumption of livestock protein and other animal products such as milk, meat, and eggs also differ from household to household.

Despite its importance in helping to improve food security and other socioeconomic profiles of the people within an economy, livestock plays an undeniable role in climate change and global warming menace. According to Gerber et al. (2013), the livestock sector is responsible for about $14.5 \%$ of the total anthropogenic greenhouse gas emissions. Livestock is thus, associated with issues of greenhouse gas emission and with the circumstances of its production, livestock poses a variety of environmental issues leading to environmental degradation. Also, with regards to population increase, this implies that more land space and other resources are required. The implication is that increased livestock production would require a significant amount of natural resources (Grossi et al., 2018). For instance, this would increase the competition for water and land meant for human welfare, settlements and crop farming. Nevertheless, in a bid to achieve food security and indeed, the necessary protein and energy needs of the human population, an improvement in animal production, particularly livestock production, is necessary. Such improvement can be achieved with regards to technologies that would take into consideration the need for environmental sustainability and land/water resource conservation for other important purposes. Also, with regard to environmental concerns, there is a need to ensure a decrease in the intensity of greenhouse gas emissions from the livestock sector (Grossi et al., 2018).

On the other hand, before the gap between energy and protein needs and supply are met, there must be a sustainable way of improving the livestock sector in order to supply these nutrients, because imbalances of nutrients due to lack of good quality food result to malnutrition, exposing the body to diseases and poor development. Food insecurity as a global issue results to chronic hunger, malnutrition in children and adults, global food shortages, high food prices, and poverty. The situation can be attributed to poor investment in the agricultural sector in terms of research, rural infrastructure, input supply, irrigation and subsidy, as well as climate change.

To achieve food security is significant especially in the developing countries, being that health, education and ability to work by certain groups of people are attributed to food security status. Meanwhile, women and children are the most vulnerable to food insecurity because they have less access to resources than men (CIDA, 2011). Sen (1981), stated that the main reason for food insecurity was access to food rather than poverty and poor income. This conforms with the definition of food security by FAO (1996), which states that food security exists when all people, at all times, have physical and economic access 
to sufficient, safe, and nutritious food to meet their dietary needs and food preferences for an active and healthy life.

A recent report by the Food and Agriculture Organisation (FAO) on the food insecurity state in the world reveals that access and availability of food can be a link to age and gender structures as well as the income distribution of the country (FAO, 1999). To analyse food insecurity and access to food at the household level, there is need to consider the level of access to inputs, and financial services given to farm families, as well as rural infrastructure being established, these are the primary elements of rural food insecurity (Omonona \& Adetokunbo, 2007). Upon the estimates by FAO by 2050, food insecurity will still persist, hence there is need to strengthen research institutions if global food production must increase by $70 \%$ as proposed by $\mathrm{FAO}$ (CIDA, 2011).

Despite improvements in agricultural production in some countries over the years, there is still insufficient food to take care of all human races, while lack of adequate food supply to all people is still a problem. A further report by Action Aid; a non-governmental organisation estimates that about US\$ 450bn is the cost of loses to GDP yearly from food insecurity in developing countries (EIU, 2012). Food demand in Nigeria is increasing with respect to population, leading to increased need for cereals such as rice and wheat, hence most food demand is met through food imports (Ukpong et al., 2013). The energy intake per person per day is about $2710 \mathrm{kcal}$ (FAOSTAT, 2010), that an average family size of five people needs about 1.5 tonnes of grain per year to meet their energy requirement. The most consumable food crops are cereals and tubers, which are produced under rain-fed agriculture, and their production has been limited by lack of water availability and poor soil fertility among others. This confirms the projections by the World Bank that Nigeria will experience increased food demand between 2000 and 2025 (NINCID, 2009).

Nigeria is the most populated black nation in the world with an estimated population of 166.63 million people in 2012 , with population growth rate of $2.55 \%$ per year (FAO, 2012). Out of this population, majority of the people live on less than $£ 1$ a day, about $20 \%$ of the population are malnourished, and almost a million die of hunger-related issues every year (FAO, 2012). The country has a land area of 98.3 million hectares, about 74 million hectares is used for arable farming (FAO, 2005), with a human development index of 0.423 , unemployment rate of $23.9 \%$, and life expectancy at birth of 52.05 years (NBS, 2012). $80 \%$ of the population are poor, living in rural areas, depending on agriculture for livelihood (Bello \& Raslan, 2010).

Agricultural sector seems to have been abandoned to the elderly people, as most young people prefer to migrate to urban cities in search of white-collar jobs, there is shortage of domestic staple food supplies in the local markets, while few ones produced are highlypriced, and there are few hires paid labourers to work in the farms. Food insecurity is definitely at an alarming rate as the population goes higher, meanwhile, the elderly population will not be able to produce enough food to cater for the teeming population, and the international market. Moreover, issue of extension agents to start demonstration farms for the local people is far gone, there are no new ideas of farming practices in the rural areas, hence, farmers still continue with the olden systems of farming that started in ages, no doubt, there is intense 
poverty in the country especially in the rural areas where a high percentage of the farmers live.

The livestock sector in Nigeria also depends mainly on native pasture, browse materials and plant residues in the different agro-ecological zones. There is no improved system to provide adequate feeding and balanced ration for the animals, yet these animals provide a variety of functions such as farm power, transport, income from meat and milk, food for human consumption, helping to enhance growth in the economy (Shiawoya $\&$ Tsado, 2011). The rise in food import in Nigeria is so glaring and worrisome, hence this study will attempt to justify if the livestock sector has the potential of improving the protein and energy supply to meet the needs of the population, as well as alleviating food insecurity in Nigeria by 2050 .

Thus, the main objective of this study is to assess the contribution of livestock to meeting the protein and energy needs of the Nigerian population. The specific objectives are:

1. To estimate energy and protein requirements for the Nigerian population using projected figures from 2012 to 2050.

2. To assess the potentials of animal-derived food to meet the needs of the population by 2050 .

\section{Materials and methods}

Secondary data were used for the study. The annual time series data sets of estimated and projected population and animal-derived food production for Nigeria were collected from recognised research institutions and corporate organizations such as the Food and Agricultural Organisation (FAO), World Bank, and the Central Bank of Nigeria. The annual time series data sets for ruminant and non-ruminant livestock production were mainly for the period between 1980 and 2010. The data include cattle milk and meat production in Nigeria, meat production from sheep and goats, poultry eggs and meat production, meat production from pigs, as well as the estimated and projected population data for Nigeria. The projected population figures were for the period between 2012 and 2050. However, data on cheese and butter were not considered, as the data on milk production included that which will go into products.

To achieve the main aim of the study, the research started with a review on global food insecurity and food insecurity trend in Nigeria, how it affected the global population, having a greater impact on developing countries.

\section{Method of Data Analysis}

Analyses were made, using available data between 1980 and 2010; to calculate the estimated energy and protein needs of the Nigerian population by 2050 . The extent to which animal-derived food can contribute to the protein and energy requirements of the people was also calculated. Moreover, simple graphs and tables were used to present data and results for the animal-derived food production and the population figures.

The energy and protein values of foods (cattle meat and milk, goat and sheep meat, pig meat, eggs and meat from poultry) were values given in the McCance and Widdowson's composition of foods base on the UK recommendations (Food Standards Agency, 2002).

McCance and Widdowson's composition is important for estimating the nutrient content of food and provides the established and accepted source of information required for nutritional labelling (Church, 2015). As 
also noted by Robertson (2003), McCance and Widdowson's composition of foods has been extensively developed and composes a valuable reference tool for studies on food and nutrient consumption. The composition which was first published in the 1930s has been extended to incorporate information on a wide range of food items and to update the nutrient composition of traditional items. According to Church (2012), the McCance and Widdowson's composition provides authoritative and comprehensive nutrient data for over 1200 of the most commonly consumed foods, thus remains an essential reference compendium for studies on the nutritional value of foods especially those consumed in the UK. Of a fact, no nutrient database can be completely accurate (Robertson, 2003), however, the McCance and Widdowson's model complements the discourse on the subject matter of this research.

\section{Results and discussion}

The McCance \& Widdowson's food composition database provides a wide range of information on varieties of food; the actual type of food that was used in the study based on the judgement of the food code number that best suited is represented in Table 1. The protein and energy values used for the calculation are also represented.

TABLE 1

Food composition data used

\begin{tabular}{llllllll}
\hline Food variable & $\begin{array}{l}\text { Cattle } \\
\text { meat }\end{array}$ & $\begin{array}{l}\text { Goat } \\
\text { meat }\end{array}$ & $\begin{array}{l}\text { Sheep } \\
\text { meat }\end{array}$ & Cow milk & $\begin{array}{l}\text { Poultry } \\
\text { eggs }\end{array}$ & $\begin{array}{l}\text { Poultry } \\
\text { meat }\end{array}$ & $\begin{array}{l}\text { Pig } \\
\text { meat }\end{array}$ \\
\hline $\begin{array}{l}\text { Food code } \\
\text { number }\end{array}$ & $18-469$ & $18-187$ & $18-187$ & $12-318$ & $12-918$ & $18-331$ & $18-258$ \\
$\begin{array}{l}\text { Energy value } \\
(\mathrm{MJ} / \mathrm{Kg})\end{array}$ & 9.34 & 11.59 & 11.59 & 2.79 & 6.27 & 7.42 & 10.24 \\
$\begin{array}{l}\text { Protein content } \\
(\mathrm{g} / \mathrm{kg})\end{array}$ & 197 & 244 & 244 & 33 & 125 & 273 & 193 \\
\hline
\end{tabular}

Based on the assumptions for the energy and protein requirement calculations, children were represented by the population in the age range of $0-14$ years while adults were identified to be 15 years and above. Productivity and expected energy and protein requirements per person per day were calculated based on the Dietary Reference Values for energy and protein given by the Scientific Advisory Committee on Nutrition (2012), which are represented in Table 2. 
The Livestock Sector and its contributions to the Protein and Energy needs...

TABLE 2

Protein and energy requirements used based on the Scientific Advisory Committee on Nutrition (2012)

\begin{tabular}{lllll}
\hline Population & Men & $\begin{array}{l}\text { Male } \\
\text { children }\end{array}$ & Women & $\begin{array}{l}\text { Female } \\
\text { children }\end{array}$ \\
\hline $\begin{array}{l}\text { Energy } \\
(\mathrm{MJ} / \mathrm{d})\end{array}$ & 10.9 & 4.9 & 8.7 & 4.6 \\
Protein (g/d) & 55.5 & 26.2 & 45 & 24.6 \\
\hline
\end{tabular}

The projected population figures were used to calculate the expected energy and protein requirements of adult females and children as well as adult males and children. The result from the developed Excel spreadsheet programme is represented in Table 3.

TABLE 3

Historical and projected population with energy and protein requirement by 2050

\begin{tabular}{|c|c|c|c|}
\hline Year & Total Population & Energy required $M J / d$ & Protein required $\mathrm{kg} / \mathrm{d}$ \\
\hline 2010 & 158423 & 1226096872 & 6354284 \\
\hline 2011 & 162471 & 1257448027 & 6516751 \\
\hline 2012 & 166629 & 1289666415 & 6683713 \\
\hline 2013 & 170901 & 1322767499 & 6855249 \\
\hline 2014 & 175288 & 1356742844 & 7031316 \\
\hline 2015 & 179791 & 1391624779 & 7212081 \\
\hline 2016 & 184411 & 1427404870 & 7397501 \\
\hline 2017 & 189144 & 1464074684 & 7587532 \\
\hline 2018 & 193976 & 1501503504 & 7781496 \\
\hline 2019 & 198889 & 1539559206 & 7978709 \\
\hline 2020 & 203869 & 1578132154 & 8178604 \\
\hline 2021 & 208911 & 1617185806 & 8380989 \\
\hline 2022 & 214018 & 1656741244 & 8585975 \\
\hline 2023 & 219196 & 1696837824 & 8793766 \\
\hline 2024 & 224453 & 1737559880 & 9004799 \\
\hline 2025 & 229796 & 1778938332 & 9219234 \\
\hline 2026 & 235227 & 1820995671 & 9437189 \\
\hline 2027 & 240742 & 1863702380 & 9658509 \\
\hline 2028 & 246345 & 1907079542 & 9883305 \\
\hline 2029 & 252035 & 1951144023 & 10111663 \\
\hline 2030 & 257815 & 1995894417 & 10343577 \\
\hline 2031 & 263684 & 2041332132 & 10579054 \\
\hline
\end{tabular}




\begin{tabular}{llll}
2032 & 269641 & 2087448732 & 10818050 \\
2033 & 275687 & 2134251246 & 11060602 \\
2034 & 281819 & 2181717184 & 11306593 \\
2035 & 288038 & 2229853574 & 11556059 \\
2036 & 294340 & 2278630901 & 11808848 \\
2037 & 300725 & 2328046351 & 12064945 \\
2038 & 307189 & 2378071814 & 12324204 \\
2039 & 313729 & 2428681990 & 12586495 \\
2040 & 320341 & 2479847362 & 12851663 \\
2041 & 327023 & 2531551062 & 13119623 \\
2042 & 333772 & 2583770603 & 13390258 \\
2043 & 340583 & 2636458193 & 13663319 \\
2044 & 347450 & 2689592751 & 13938697 \\
2045 & 354369 & 2743118052 & 14216102 \\
2046 & 361336 & 2797004582 & 14495380 \\
2047 & 368348 & 2851243906 & 14776488 \\
2048 & 375401 & 2905805101 & 15059265 \\
2049 & 382491 & 2960643191 & 15343477 \\
2050 & 389615 & 3015732874 & 15628995 \\
\hline
\end{tabular}

Animal Derived Food Production, and Energy and Protein Supply Based on the Excel spreadsheet programme developed, Table 4 shows the productivity of animalderived food from 1980 to 2010 and the energy and protein supplied by these foods. 
The Livestock Sector and its contributions to the Protein and Energy needs...

TABLE 4

Animal-derived food production, and energy and protein supply for Nigeria

\begin{tabular}{|c|c|c|c|c|c|c|c|c|c|c|c|}
\hline Year & $\begin{array}{c}\text { Cattle } \\
\text { meat } \\
(\mathrm{t} / \mathrm{y})\end{array}$ & $\begin{array}{c}\text { Goat Meat } \\
(\mathrm{t} / \mathrm{y})\end{array}$ & $\begin{array}{c}\text { Sheep } \\
\text { Meat } \\
(t / y)\end{array}$ & $\begin{array}{c}\text { Cow Milk } \\
(t / y)\end{array}$ & $\operatorname{Eggs}(t / y)$ & $\begin{array}{c}\text { Poultry } \\
\text { meat } \\
(\mathrm{t} / \mathrm{y})\end{array}$ & $\begin{array}{l}\text { Pig meat } \\
(\mathrm{t} / \mathrm{y})\end{array}$ & $\begin{array}{l}\text { Energy } \\
\text { supplied } \\
(\mathrm{MJ} / \mathrm{y})\end{array}$ & $\begin{array}{l}\text { Protein } \\
\text { supplied } \\
(\mathrm{kg} / \mathrm{y})\end{array}$ & $\begin{array}{l}\text { Energy } \\
\text { supplied } \\
(\mathrm{MJ} / \mathrm{d})\end{array}$ & $\begin{array}{l}\text { Protein } \\
\text { supplied } \\
(\mathrm{kg} / \mathrm{d})\end{array}$ \\
\hline 1980 & 370216 & 59055 & 28050 & 290000 & 200000 & 118000 & 38250 & 7797704390 & 168352422 & 21363574 & 461240 \\
\hline 1981 & 329125 & 64135 & 30800 & 292000 & 205000 & 131000 & 38250 & 7638054150 & 166408015 & 20926176 & 455912 \\
\hline 1982 & 364231 & 71120 & 31350 & 297000 & 220000 & 122000 & 38250 & 8094494840 & 174745437 & 22176698 & 478755 \\
\hline 1983 & 411797 & 76835 & 32450 & 301000 & 225000 & 135000 & 38250 & 8756717130 & 190084799 & 23991006 & 520780 \\
\hline 1984 & 425918 & 82550 & 34650 & 304000 & 235000 & 128000 & 49500 & 9114672120 & 196407146 & 24971704 & 538102 \\
\hline 1985 & 437724 & 87630 & 36300 & 309000 & 250000 & 137000 & 60750 & 9592920860 & 207043298 & 26281975 & 567242 \\
\hline 1986 & 283478 & 99060 & 37400 & 315000 & 260000 & 141000 & 76500 & 8567885920 & 185293906 & 23473660 & 507655 \\
\hline 1987 & 266734 & 104140 & 38500 & 321000 & 280000 & 152000 & 92250 & 8868163160 & 192244008 & 24296337 & 526696 \\
\hline 1988 & 236049 & 110490 & 39600 & 329000 & 260000 & 160000 & 99000 & 8693310760 & 189267613 & 23817290 & 518541 \\
\hline 1989 & 217530 & 120650 & 41800 & 339000 & 243000 & 169000 & 114750 & 8812965700 & 192336960 & 24145112 & 526951 \\
\hline 1990 & 204273 & 120650 & 44000 & 351000 & 337000 & 174000 & 106886 & 9294075960 & 202255379 & 25463222 & 554124 \\
\hline 1991 & 205000 & 123190 & 47300 & 360000 & 359000 & 165000 & 106277 & 9458585580 & 204296021 & 25913933 & 559715 \\
\hline 1992 & 210000 & 125730 & 48400 & 370000 & 378000 & 162000 & 112500 & 9735966700 & 209256220 & 26673881 & 573305 \\
\hline 1993 & 244378 & 130556 & 50600 & 380000 & 397000 & 165000 & 117000 & 10353858560 & 222135530 & 28366736 & 608590 \\
\hline 1994 & 264319 & 143637 & 62040 & 387826 & 418000 & 168000 & 121500 & 11046150430 & 236617789 & 30263426 & 648268 \\
\hline 1995 & 266861 & 156337 & 65890 & 394008 & 390000 & 169000 & 130500 & 11202974990 & 239870769 & 30693082 & 657180 \\
\hline 1996 & 280000 & 169545 & 68750 & 406771 & 325000 & 170000 & 135000 & 11193480140 & 239817423 & 30667069 & 657034 \\
\hline 1997 & 294000 & 182527 & 87010 & 350000 & 279000 & 171000 & 139500 & 11293023830 & 243716528 & 30939791 & 667717 \\
\hline 1998 & 297000 & 194691 & 95205 & 367500 & 419000 & 172000 & 144000 & 12537129640 & 268494124 & 34348300 & 735600 \\
\hline 1999 & 298000 & 206502 & 105490 & 385875 & 435000 & 172000 & 153000 & 13046308530 & 278425923 & 35743311 & 762811 \\
\hline 2000 & 279000 & 221234 & 115390 & 389000 & 400000 & 160000 & 157500 & 12900642160 & 274013756 & 35344225 & 750723 \\
\hline 2001 & 283432 & 238618 & 127820 & 389300 & 440000 & 183500 & 165375 & 13794228300 & 295106751 & 37792406 & 808512 \\
\hline 2002 & 279500 & 242264 & 129943 & 408200 & 450000 & 190000 & 192524 & 14266032890 & 304627740 & 39085022 & 834597 \\
\hline 2003 & 267270 & 245373 & 131271 & 408700 & 460000 & 201000 & 178875 & 14209178760 & 304936301 & 38929257 & 835442 \\
\hline 2004 & 280000 & 251841 & 143332 & 423000 & 476000 & 211000 & 186165 & 14831894670 & 318574057 & 40635328 & 872806 \\
\hline 2005 & 260850 & 256746 & 137302 & 438500 & 500400 & 218750 & 193455 & 14968382520 & 321611227 & 41009267 & 881127 \\
\hline 2006 & 284050 & 264318 & 141438 & 462700 & 526400 & 232100 & 201285 & 15730540440 & 338242719 & 43097371 & 926692 \\
\hline 2007 & 287450 & 270662 & 144722 & 468240 & 552800 & 243300 & 209250 & 16219535160 & 349339416 & 44437083 & 957094 \\
\hline 2008 & 293800 & 277433 & 145321 & 469250 & 581000 & 243250 & 217602 & 16629047840 & 357545262 & 45559035 & 979576 \\
\hline 2009 & 298350 & 284266 & 148809 & 472320 & 612600 & 256500 & 226307 & 17185316730 & 370308561 & 47083060 & 1014544 \\
\hline 2010 & 303600 & 291300 & 148809 & 495800 & 623400 & 256500 & 226307 & 17449100990 & 375183947 & $47,805,756$ & $1,027,901$ \\
\hline
\end{tabular}

As indicated in Table 4, from the Excel programme, total energy and protein production from animal-derived food for 2010 were $47,805,756 \mathrm{MJ} / \mathrm{d}$ and $1,027,901 \mathrm{~kg} / \mathrm{d}$ respectively. This indicates an obvious increase in total energy and protein supplied from animal-de- rived food from 1980. The results also indicate an increase in energy supplied per year from $7,797,704,390 \mathrm{MJ} / \mathrm{y}$ in 1980 to $17,449,100,990$ $\mathrm{MJ} / \mathrm{y}$ in 2010 , and that of protein supplied per year from $168,352,422 \mathrm{~kg} / \mathrm{y}$ in 1980 to $375,183,947 \mathrm{~kg} / \mathrm{y}$ in 2010 . 
Protein requirement for the projected population between 2010 and 2050

From the result in Table 3, the protein requirement in 2010 was subtracted from the expected protein requirement per day by the projected Nigerian population in 2050; as indicated in equation 1.

$[(15628995-6354284 \mathrm{~kg} / \mathrm{d})=9274712 \mathrm{~kg} / \mathrm{d}]$

Hence, the estimated extra protein required by the Nigerian population by 2050 is $9,274,712$ $\mathrm{kg} /$ day. The amount that will be required by adults and children is $6,868,504 \mathrm{~kg} / \mathrm{d}$ and 2,406,207 kg/d respectively. However, the percentage (\%) extra animal-derived foods that would be needed to provide the additional protein required by the projected population by 2050 equals the ratio of total estimated protein required by the population between 2010 and 2050 , and the current protein production from animal-derived food in 2010;

The percentage (\%) extra animal-derived foods that would be needed to provide the additional protein $(\mathrm{kg} / \mathrm{d})$ is calculated in equation 2:

$$
\left[(2010-2050)=\frac{9274712}{1072901} \times 100=9.0 \%\right]
$$

Energy requirement for the projected population between 2010 and 2050

The energy requirement in 2010 was subtracted from the extra energy requirement by the projected Nigerian population for 2050 to get the extra energy required for the Nigerian population as shown in equation 3 :

$[(3015732874-1226096872 M J / d)=1789636001 M J / d]$

Therefore, the estimated extra energy required by the Nigerian population by 2050 is $1,789,636,001 \mathrm{MJ} / \mathrm{d}$, out of this number, 1,339655,588 MJ/d and 449,980,413 MJ/d will be required by adult and children respectively.
Hence, the percentage increase in animalderived food needed to provide the extra energy, required by the projected population by 2050 equals the ratio of total estimated energy required by the population between 2010 and 2050 , and the energy production from animalderived food by 2010 ;

Thus, the percentage (\%) extra animal-derived foods that would be needed to provide the additional energy can be estimated as follows:

$\left[(M J / d)(2010-2050)=\frac{1789636001}{47805756} \times 100=37.4 \%\right]$

Total energy and protein requirement by the Nigerian population; current production as well as extra increase in production needed for 2050 as calculated using the Excel programme and as indicated in equation 4 , are summarised in Table 5.

TABLE 5

Energy and protein requirement, current production, and extra increase in production for Nigeria by 2050

\begin{tabular}{lll}
\hline Population & Energy $(\mathrm{MJ} / \mathrm{d})$ & Protein $(\mathrm{kg} / \mathrm{d})$ \\
\hline $\begin{array}{l}\text { Adults }(15 \\
\text { years and } \\
\text { above) }\end{array}$ & $1,339,655,588$ & $6,868,504$ \\
$\begin{array}{l}\text { Children (0 } \\
\text {-14years) }\end{array}$ & $449,980,413$ & $2,406,207$ \\
$\begin{array}{l}\text { Total } \\
\text { Current } \\
\text { production } \\
\text { \% requirement }\end{array}$ & 3.71 & \\
$\begin{array}{l}\text { Extra increase } \\
\text { in production } \\
\text { needed for }\end{array}$ & 37.4 & $1,027,909,636,001$ \\
\begin{tabular}{l} 
2050 (\%) \\
\hline
\end{tabular} & & 9.0 \\
\hline
\end{tabular}


The result in Table 5 indicates that the total energy and protein requirements per day by the projected Nigerian population by 2050 would be $1,789,636,001 \mathrm{MJ} / \mathrm{d}$ and $9,274,712 \mathrm{~kg} / \mathrm{d}$ respectively, with projected requirements for adults (15 years and above) indicated as $1,339,655,588 \mathrm{MJ} / \mathrm{d}$ of energy and $6,868,504 \mathrm{~kg} / \mathrm{d}$ of protein, while those of Children ( 0 - 14years) would be 449,980,413 $\mathrm{MJ} / \mathrm{d}$ of energy and 2,406,207 $\mathrm{kg} / \mathrm{d}$ of protein. The percentage (\%) requirements are indicated as $3.71 \%$ and $15.38 \%$ of energy and protein respectively, with an extra increase in production needed by 2050 projected at $37.4 \%$ and $9.0 \%$ of energy and protein respectively.

\section{Conclusion}

The cumulative population growth in the world has raised debatable concerns as it results in food security issues including inefficient nutritional balance, geometrically increasing food demand and high food prices.

In particular, livestock production is one of the major sources of livelihood for the poor farm families in Africa and other developing countries in the world. Livestock contributes to the provision of food and income, and reduces unemployment rate, reduces hunger and malnutrition. It provides protein and other nutrients for the human body, serves as a source of wealth creation, provides transport, and enhances the livelihood of resource-poor farmers.

By inferences, the study has shown a relationship between the livestock sector and food security, having indicated the sector's contributions to the energy and protein requirements of the Nigerian population, hence an improvement in the livestock sector could lead to a substantial improvement in food security in the country.
In particular, the result of this study indicates a gap between current production and expected protein and energy requirement of the Nigerian population by 2050 and suggests that animal-derived foods would have to supply $37.4 \%$ more energy and $9.0 \%$ more protein than in 2010 to meet the additional energy and protein needs of the projected Nigerian population of 389.615 million people by 2050 . To ensure the certainty of the contributions of the livestock sector to the protein and energy requirements of the increasing population, there is a need to achieve greater productivity in livestock production.

The study suggests the need for the government, research institutions and the private sector to encourage livestock farmers towards achieving increased productivity by providing enabling policies, collaborative research, innovations and financial support as the case may be. In particular, there is a need for increased investment in the livestock sector to help improve the quality and availability of feed materials; a prospect that requires consistent investment and support from the government and other stakeholders in the economy. Also, there is a need for suitable policies to support livestock farmers especially the small-scale farmers through the provision of incentives, subsidies, good veterinary care, and good breeding programmes. There is also the need to enhance productivity from other sectors of the economy such as crop production; to ensure adequate food production and supply in the country to meet up the extra protein and energy needs of the population by 2050 .

More so, agricultural policies should be made to address issues of subsistence agriculture whereby people produce food only to take care of their family needs, without any remains for the markets, hence could not 
generate enough income to take care of their basic needs, leading to increased poverty. Since agriculture has a greater role to play in sustaining the general economy of the country as the population increases, there is a need for the government to look into other food insecurity coping mechanism, while making effort to restore the livestock sector, to ensure sustainability and general development of the overall economy of Nigeria.

On the whole, the study encourages a consistent commitment to livestock production to help enhance productivity, improve food security and better the wellbeing of farmers, as well as improve economic development in the country. On the other hand, the study reiterates the need to encourage improved technology and innovation that would particularly promote environmental sustainability by helping to reduce greenhouse gas emissions and other environmental impacts associated with livestock production.

More so, having considered a wide range of data spanning over 30 years (19802010), this study thus creates a significant reference background for further research and comparison with regards to the subject matter.

\section{Conflict of interest}

Authors do not have any conflict of interest.

Acknowledgement

Authors appreciate the supervisory assistance and support from Prof. Ian Givens, University of Reading, United Kingdom.

\section{REFERENCES}

Bello, M. A. \& Roslan, A. H. (2010) Has poverty reduced in Nigeria. European Journal of Science 15 (1), 7 - 17.
Church, S. M. (2015) The importance of food composition data in recipe analysis. Nutritional Bulletin 40 (1). DOI: 10.1111/nbn.12125.

Church, S. M. (2012) McMance and Widdowson's the composition of foods. Royal Society of Chemistry 31 (6), pp. 554.

CIDA (2011) Increasing food security: CIDA's food security strategy. Canada: Canadian International Development Agency.

Crentsil, C. \& Ukpong, I. G. (2014) Production function analysis of fish production in Amansie-West District of Ghana, West Africa. American Journal of Experimental Agriculture 4 (7), 817 - 835. DOI: 10.9734/AJEA/2014/8625.

Diaz- Bonilla, E., Thomas, M. \& Robinson, S. (2000) Food Security And Trade Negotiations In The World Trade Organisation: A cluster analysis of country groups. Washington, D.C: International Food Policy Research Institute.

EIU (2012) Global Food Security Index 2012: An assessment of food affordability, availability and quality. London, United Kingdom: Economist Intelligence Units.

FAO (1996) Rome declaration on world food security and world food summit plan of action. World Food Summit. Rome, Italy: Food and Agricultural Organization of the United Nations.

FAO (2005) Nigeria's agricultural and food security challenges. Retrieved April 20, 2012, from Food and Agricultural Organization: $\underline{w w w . f a o}$. org.

FAO (2012) Food Security Portal. Food and Agricultural Organization. Available: http://www. foodsecurityportal.org/nigeria.

FAOSTAT (2010) Food Balance Sheets. Rome, Italy: Food and Agricultural Organization of the United Nations. Available: http://www.fao. org/faostat/en/\#data/FBS/report . 
Food Standards Agency (2002) McCance and Widdowson's The Composition of Foods, Sixth Summary Edition. Cambridge: Royal Society of Chemistry.

Gerber, P.J., Steinfeld, H., Henderson, B., Mottet, A., Opio, C., Dijkman, J., Falcucci, A., \& Tempio, G. (2013) Tackling climate change through livestock: A global assessment of emissions mitigation opportunities. Food and Agricultural Organization of the United Nations (FAO), Rome, Italy. Available: http:// agris.fao.org/agris-search/search.do?recor$\mathrm{dID}=$ XF2016016977.

Grossi, G., Goglio, P., Vitali, A. \& Williams, A. G. (2018) Livestock and climate change: Impact of livestock on climate and mitigation strategies. Animal Frontiers 9 (1), $69-76$.

Huang, Y. \& Ukpong, I.G. (2019) Issues of water resource management in China: Implications on agriculture and food security in the Guangxi Province of South China. Journal of Asian Rural Studies 3 (1), 70 - 84.

NBS (2012) Agricultural statistics. Nigeria: Nigeria National Bureau of Statistics.

NINCID (2009) Nigeria. Nigeria National Committee of ICID (NINCID.

Omonona, B. T. \& Adetokunbo, A. G. (2007) An analysis of food security situation among $\mathrm{Ni}$ gerian urban households: Evidence from La- gos State, Nigeria. Journal of Central Agriculture 8 (3), $397-406$.

Robertson, C. (2003) McMance and Widdowson's the composition of foods-sixth edition. $\mathrm{Nu}$ trition Bulletin 28 (1). DOI: 10.1046/j.14673010.2003.00292.x.

Scientific Advisory Committee on Nutrition (2012) The Scientific Advisory Committee on Nutrition annual report for the calendar year 2012. Available:https://www.gov.uk/government/ publications/sacn-annual-report-2012.

Sen, A. (1981) Poverty and famines: An essay on entitlement and deprivation. Oxford: Clarendon Press.

Shiawoya, E. L., Fasanya, O. O. A. \& Ikhatua, U. J. (2001) Feedlot performance of yankasa rams fed a year-round diet of groundnut haulms, gmelina leaves and concentrates 4 (2), 134 149.

Ukpong, I. G., Ekpebu, I. D. \& Ofem, N. I. (2013) Cointegration inferences on issues of poverty and population growth in Nigeria. Journal of Development and Agricultural Economics, USA. 5 (7), 227 - 283.

Young, H., Jaspars, S., Brown, R., Frize, J. \& Khogali, H. (2001) Food security assessments in emergencies: A livelihoods a pproach. Rome: Food and Agricultural Organization. 